\title{
Salicylic acid: physiological and biochemical changes in seeds and maize seedlings subjected to salt stress ${ }^{1}$
}

\author{
Fernanda Reolon Tonel², Patrícia Marini2** Juliana de Magalhães Bandeira², \\ Dario Munt de Moraes $^{2}$, Luciano do Amarante ${ }^{3}$
}

\begin{abstract}
Several plant species have development limitations on saline soils; however under water stress situations salicylic acid (SA) may have defense function by acting as antioxidant. Thereby, this study was aimed at analyzing physiological changes occurring in maize seeds treated with SA and germinated on sodium chloride moistened substrate; as well as assessing the effect of antioxidant enzymes produced by the seedlings. To this, seeds were soaked into zero and $1 \mathrm{mM}$ SA solutions, for 60 min., and germinated on different $\mathrm{NaCl}$ concentrations $(0,30,90$, and $180 \mathrm{mM})$, and afterwards evaluated for germination, germination speed index, initial growth, and effect of antioxidant enzymes on seedlings. For electrical conductivity test, the seeds were previously soaked in $\mathrm{NaCl}$ solutions with and without SA. The SA application has minimized damages induced by salt stress to maize seed germination by favoring their germination percent; however without SA was not able on maintaining seed viability over $90 \mathrm{mM}$. Seedling initial growth was impaired by increasing $\mathrm{NaCl}$ concentrations in substrate; and electric conductivity has shown low values for release of solutes in the presence of SA. Activity of antioxidant enzymes has increased until $30 \mathrm{mM} \mathrm{NaCl}$ concentration; however above such concentration activity of these enzymes was reduced. The SA maintains germination of corn seeds above $90 \mathrm{mM} \mathrm{NaCl}$; however, generally it is not efficient to ensure vigor of seedlings.
\end{abstract}

Index terms: Zea mays, antioxidant enzymes, $\mathrm{NaCl}$, seed viability, seedling growth.

\section{Ácido salicílico: modificações fisiológicas e bioquímicas em sementes e plântulas de milho submetidas ao estresse salino}

\begin{abstract}
RESUMO - Diversas espécies apresentam limitações no desenvolvimento em solos salinos, entretanto, em situações de estresse, o ácido salicílico (AS) pode apresentar função antioxidante. Portanto, objetivou-se analisar modificações fisiológicas em sementes e plântulas de milho tratadas com AS e germinadas em cloreto de sódio, além das respostas do sistema antioxidante em plântulas. As sementes foram embebidas durante 60 minutos em soluções de AS (zero e $1 \mathrm{mM}$ ) e colocadas para germinar nas concentrações de $\mathrm{NaCl}$ (zero; 30; 90 e $180 \mathrm{mM}$ ), sendo avaliadas quanto a germinação, índice de velocidade de germinação, crescimento inicial e atividade de enzimas antioxidantes das plântulas. Para a condutividade elétrica, as sementes foram embebidas em mistura das soluções de $\mathrm{NaCl}$ e AS. O AS minimizou os danos causados pela salinização na germinação, que foi prejudicada a partir de $90 \mathrm{mM}$ de $\mathrm{NaCl}$, na ausência de AS. O crescimento inicial foi prejudicado com o aumento das concentrações salinas, enquanto a condutividade elétrica apresentou menor lixiviação de solutos na presença do AS. Houve aumento na atividade das enzimas antioxidantes até $30 \mathrm{mM}$ de $\mathrm{NaCl}$ com posterior redução. O AS mantêm a germinação das sementes de milho acima de $90 \mathrm{mM}$ de $\mathrm{NaCl}$, porém, de maneira geral, não é eficiente para garantir o vigor das plântulas.
\end{abstract}

Termos para indexação: Zea mays, enzimas antioxidantes, $\mathrm{NaCl}$, viabilidade de sementes, crescimento de plântulas.

\section{Introduction}

The majority of plant species worldwide grown is constantly exposed to biotic and abiotic stresses, and among them is the salt stress. The excess of salts in the root environment, caused by improper management of irrigation water, by the very

${ }^{1}$ Submitted on $02 / 25 / 2013$. Accepted for publication on $08 / 15 / 2013$.

${ }^{2}$ Departamento de Botânica, UFPel, Caixa Postal 354, 96010-900 - Capão do Leão, RS, Brasil. characteristic of the pedogenisis and edaphoclimatic conditions, salt stress may affect growth and productivity of many crops (Santos et al., 2009; Islã and Aragués, 2010). In Brazil, despite data on the areas with salinized soil are not very accurate it is estimated that circa $20 \%$ to $25 \%$ of the irrigated areas present salinization problems (FAO, 2006). In such environments

${ }^{3}$ Departamento de Química e Geociências, UFPel, Caixa Postal 354, 96 010-900 Capão do Leão, RS, Brasil.

*Corresponding author <marinipati@gmail.com> 
the sodium chloride $(\mathrm{NaCl})$ is the predominant salt and may impair germination of seeds and development of plants of several plant species.

Adaptation of different crops to diverse environmental stress conditions is the result of the occurrence of different integrated events during the several crop developmental stages involving changes in the cell morphology, as well as in the anatomical and biochemical alterations occurring in the plant characteristics (Bueno et al., 2006). These changes are resulting from the disorders occurring in the water relationships, and in the absorption and utilization of essential nutrients by plants, which are caused by the excess salt in the soil (Jaleel et al., 2008; Amorim et al., 2010).

When exposed to excess salts in the root environment, the majority of cultivated plants produce excessive amounts of reactive oxygen species (ROS) such as the radicals superoxide $\left(\mathrm{O}_{2}{ }^{-}\right)$, hydroxyl $\left(\mathrm{OH}^{\bullet-}\right)$, hydrogen peroxide $\left(\mathrm{H}_{2} \mathrm{O}_{2}\right)$ and singlet oxygen $\left({ }^{1} \mathrm{O}_{2}\right)$ (Apel and Hirt, 2004; Møller et al., 2007; Joseph and Jini, 2011). Excessive production of such functional groups of radicals may limit growth and development of plants by oxidation of the cell membranes lipids (Forman et al., 2010).

To restrain deleterious effects of ROS the plants have developed a complex antioxidant system, which constitutes their primary defense against these free radicals generated under stress conditions (El-Shabrawi et al., 2010); as for example, the enzyme superoxide dismutase (SOD) that catalyzes the dismutation reaction from the radical superoxide $\left(\mathrm{H}_{2} \mathrm{O}_{2}\right)$ to $\mathrm{H}_{2} \mathrm{O}+\mathrm{O}_{2}$, and the enzymes ascorbate peroxidase (APX) and catalase (CAT) that can also break the $\mathrm{H}_{2} \mathrm{O}_{2}$ molecule releasing $\mathrm{H}_{2} \mathrm{O}$ and $\mathrm{O}_{2}$ (Deuner et al., 2011).

The balance between ROS production and the ability to fast triggering a defense system, against the antioxidative stress imposed, reflects the capacity of plants in adapting to the adverse conditions; thus characterizing their higher resistance (Parida and Das, 2005). Besides the enzymatic defense system, plants may also respond to the oxidative stress conditions by formation of secondary metabolites such as the salicylic acid; which also features defensive function against various types of stresses, mainly due to its properties as oxi-reduction agent on the citoplasm of cells membranes, as well as to its chemical structure (Soares and Machado, 2007).

The antioxidant properties of phenolic compounds, such as salicylic acid play an important role in scavenging free radicals by acting both on the initial stages as in the oxidative process propagation, which may delay or inhibit the cell membranes lipids oxidation (Sousa et al., 2007).

The exogenous application of such acid is used by the seeds in the adaptation to stress, once this compound may act by stimulating the cell wall signification, directing the pentose phosphate and shikimate pathways for producing phenolic compound (as lignin) in the treated seeds, what probably will assist on maintainability of their vigor (Pacheco et al., 2007).

In face of the foregoing, this study was aimed at analyzing physiological changes occurring in seeds and seedlings of maize (Zea mays L.) treated with salicylic acid and germinated in the presence of sodium chloride; as well as verifying the antioxidative system response on the seedlings.

\section{Material and Methods}

The study was carried out at the Seed Physiology Laboratory of Botanic Department and at the Plant Biochemistry Laboratory of Chemistry and Geosciences Department, Federal University of Pelotas, at municipality of Pelotas, state of Rio Grande do Sul, Brazil. The seeds of the three corn hybrid lots used for this study were provided by the Pioneer Corporation.

To assess seed vigor through germination test, seeds were previously soaked in a salicylic acid (SA) solution at concentration of $1 \mathrm{mM}$, for $60 \mathrm{~min}$; and by using sterile distilled water to soak the seeds used as control. Immediately after the soaking period, four samples of 50 seeds each, to each treatment were uniformly distributed upon two sheets of germination paper $\left(\right.$ Germitest $\left.^{\circledR}\right)$, moistened with $\mathrm{NaCl}$ solutions at different concentrations [0 (control), and 30, 90, and $180 \mathrm{mM} \mathrm{NaCl}]$ at a ratio of 2.5 times the dry substrate mass, and then placed into a seed germinator, set to $25^{\circ} \mathrm{C}$, for seven days (Brasil, 2009). Assessments were performed in the fourth and seventh days after sowing (DAS); and results were expressed as percentage of normal seedlings emerged in all $\mathrm{NaCl}$ concentrations studied.

Germination speed index (GSI) was assessed by the daily count of seeds displaying radicle protrusion through seed coat during the germination test, until the stand of seedlings was constant. The last count day to this test was the same prescribed to the standard germination test. The GSI was computed according to equation described by Maguire (1962).

Length of shoots and roots was obtained through computation of mean data collected from 10 seedlings of each sample originating from the three lots assessed; thus totaling 120 seedlings. Measurement for both the shoots and roots was performed with the aid of a millimeter ruler; and results were expressed as mm.seedling ${ }^{-1}$. Assessment of dry mass of shoots and roots was carried out after germination test by determining dry mass of 10 seedlings to each replication, also totaling 120 seedlings. To this, seedlings were dried in an oven, set at $70 \pm 1{ }^{\circ} \mathrm{C}$, until reaching constant mass, and then 
weighed in an analytical balance. The results were expressed as mg.seedling ${ }^{-1}$ (Marini et al., 2013).

The electrical conductivity test (EC) was carried out using four subsamples, with 25 seeds each, from each of the three seed lots. For that, mass of the dried seeds was previously determined, and then seeds were soaked into saline solutions, at concentrations of $0,30,90$, and $180 \mathrm{mM} \mathrm{NaCl}$, containing SA solution $(1 \mathrm{mM})$, or in the same $\mathrm{NaCl}$ solutions without $\mathrm{SA}$, for $60 \mathrm{~min}$. Immediately after this soaking period, the excess solution on the seeds was dried with paper towels, and the seeds were than transferred to $80 \mathrm{~mL}$ capacity flasks, containing deionized water, and incubated at $20 \pm 1{ }^{\circ} \mathrm{C}$, for different time periods. Electrical conductivity in the soaking solution was determined with the aid a conductivimeter (brand Digimed ${ }^{\circledR}$, model CD-21) after three, six and $24 \mathrm{~h}$; and results were expressed as $\mu \mathrm{S} . \mathrm{cm}^{-1} \cdot \mathrm{g}^{-1}$ seed, as function of the initial mass of the seeds used in this study (Vieira and Krzyzanowski, 1999).

Aiming at verifying the effect of salt stress on antioxidant metabolism of the maize seedlings, besides percent germination and development of the seedling originating from these seeds, the activity of the antioxidant enzymes superoxide dismutase (SOD, EC 1.15.1.1), ascorbate peroxidase (APX, EC 1.11.1.11) and catalase (CAT, EC 1.11.1.6) was also evaluated. For this evaluation, were used the seedlings emerged in the germination test, from which $300 \mathrm{mg}$ samples of living tissue were taken. This tissue was macerated in $10 \%$ polyvinylpolypyrrolidone (PVPP), and homogenized in $1.5 \mathrm{~mL}$ extraction buffer consisting of potassium phosphate (100 mM; pH 7.8), ethylenediaminetetraacetic acid (EDTA) $(0.1 \mathrm{mM})$, and ascorbic acid $(20 \mathrm{mM})$. Immediately after, the homogenate was centrifuged at $12.000 \mathrm{rpm}$, at temperature of $4{ }^{\circ} \mathrm{C}$, for $20 \mathrm{~min}$; and from the supernatant liquid of each centrifuged sample an aliquot was removed for determining activity of enzymes, as well as for quantifying the proteins by the Bradford method (Bradford, 1976).

The SOD enzyme activity was based on its ability of inhibiting photoreduction of nitroblue tetrazolium (NBT) (Giannopolitis and Ries, 1977) in the reaction medium containing $50 \mathrm{mM}$ potassium phosphate $(\mathrm{pH} 7.8)$, methionine $(14 \mathrm{mM})$ EDTA $(0.1 \mathrm{mM})$, NBT $(75 \mathrm{mM})$ and riboflavin (2 $\mathrm{mM})$ plus $50 \mu \mathrm{L}$ of enzyme extract. Readings were taken at $560 \mathrm{~nm}$ assuming a unit of SOD is the amount of enzyme able to inhibit by $50 \%$ the NBT photoreduction at the assay conditions. Activity of APX enzyme was evaluated by the rate of ascorbate oxidation and performed according to method described by Nakano and Asada (1981) with some modifications. The reaction medium, composed of potassium phosphate buffer (100 mM; pH 7.0), ascorbic acid $(0.5 \mathrm{mM})$ and $\mathrm{H}_{2} \mathrm{O}_{2}(0.1 \mathrm{mM})$ was incubated at $37{ }^{\circ} \mathrm{C}$; and before performing reading, $15 \mu \mathrm{L}$ enzymatic extract were added. The reading was performed in a spectrophotometer, at $290 \mathrm{~nm}$, for 90 seconds. Enzymatic activity of the CAT enzyme was determined by the method described by Azevedo et al. (1998) with modifications, and estimated by the decrease in absorbance read at $240 \mathrm{~nm}$, for 90 seconds, in a reaction medium containing potassium phosphate (100 Mm, pH 7.0) and $\mathrm{H}_{2} \mathrm{O}_{2}(12.5 \mathrm{mM})$, incubated at $37{ }^{\circ} \mathrm{C}$ to which $15 \mu \mathrm{L}$ of the enzyme extract were added before reading.

The assays were carried out in a completely randomized experimental design, with treatments arranged in a factorial $2 \mathrm{x}$ 4 ( 2 concentrations of salicylic acid $\mathrm{x} 4$ concentrations of salt solutions), with four replications to each treatment. Data on seed germination and seedling growth were subjected to ANOVA and to polynomial regression by using the WinStat software, version 2.0 (Machado and Conceição, 2007). Determination of the antioxidant system activity was performed by contrast analysis of orthogonal polynomials (Steel and Torrie, 1980).

\section{Results and Discussion}

Maize seeds treated with the different $\mathrm{NaCl}$ concentrations, which were not treated with SA, have shown reduction on seed germination percent from the $90 \mathrm{mM} \mathrm{NaCl}$ concentration; however, from this same concentration, treatment with SA has kept the seed percent germination at the same level (Figure 1A). These results allow inferring that presence of SA, at the $1 \mathrm{mM}$ concentration was sufficient to minimize the effect of salt stress on percent germination of the hybrid maize seeds. By using a SA solution at concentrations of $0.5 \mathrm{mM}$ and 0.025 $\mathrm{mM}$, which are below concentrations used in this study, other authors also have detected increases on percent germination of tomato (Solanum lycopersicum L.) seeds (Szepesi et al., 2005) as well as of pot marigold (Calendula officinalis L.) seeds (Carvalho et al., 2007). Thereby, the role of the salicylic acid in response to salt stress during seed germination is probably correlated to accumulation of the antioxidant enzymes proline and betaine (Deef, 2007) arising from the osmotic adjustment process, which provides resistance to the stress imposed.

Germination speed index (GSI) has decreased with increasing concentrations of $\mathrm{NaCl}$, regardless if seeds were treated or not with salicylic acid (Figure 1B). However, it is important to stress that response to SA concentration is influenced by the plant species studied as well as its sensitivity to this compound, which can function as an allelopathic component that influences seed germination and plant growth (Lynn and Chang, 1990). In tests of germination and vigor carried out on rice (Oryza sativa L.) seeds treated 
with salicylic acid, Silveira et al. (2000) have also observed that SA concentrations of 10 and $20 \mathrm{mM}$ have had phytotoxic effect on the seeds, which was possibly a consequence of cell death within the seed.
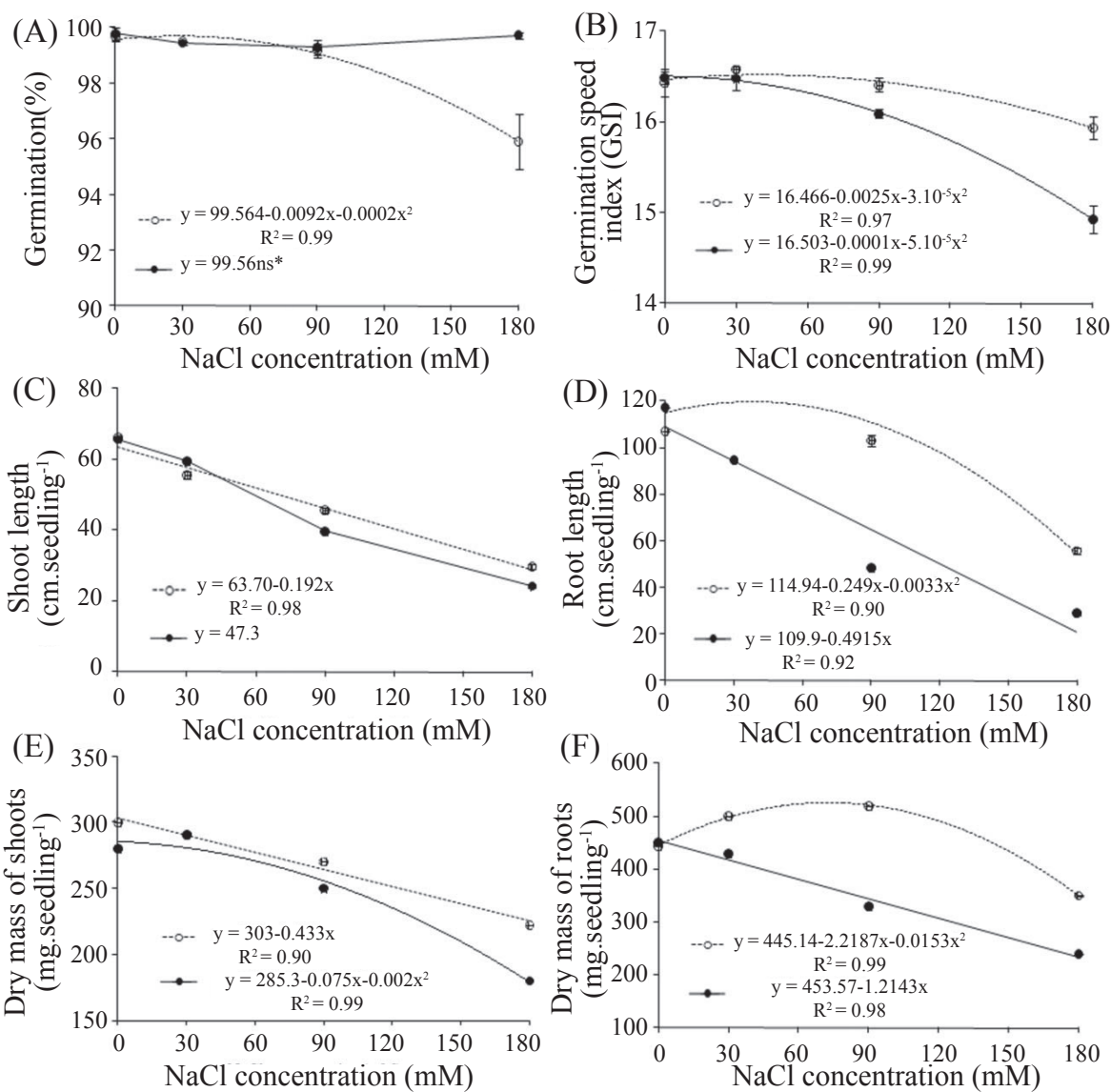

Figure 1. Linear regression curves plotted to mean values of four replications computed for germination (A); germination speed index (B); length and dry weight of shoots (C and E); and length and dry mass of roots (D and F) of maize seedlings previously soaked in a solution containing $1 \mathrm{mM}$ salicylic acid $(-\bullet)$, or in distilled water without salicylic acid (----), and grown on a substrate containing different $\mathrm{NaCl}$ concentrations. *ns $=$ non-significant by $\mathrm{F}$ test $(\mathrm{P}<0.05)$. Bars $=$ standard error of the means of four replications.

Length of the shoot and growth of root system of maize seedlings were reduced by the different $\mathrm{NaCl}$ concentrations, both in the presence as in the lack of SA (Figures 1C and 1D). This event may be attributed to decrease on water absorption in the presence of sodium chloride, followed by hydrolysis of the limited food reserves of the storage tissues, as well as due to the deficient translocation of these storage reserve tissues for the development of the embryonic axis (Khan and Panda, 2008). Whether the application of SA in hybrid corn seeds has contributed or not for reduction of the $\mathrm{NaCl}$ deleterious effect on growth of shoots, the results achieved in other studies such as those of Gunes et al. (2007) with maize seeds, and those of Deef (2007) with wheat (Triticum aestivum L.) seeds and barley (Hordeum vulgare L.) seeds have shown that this phenolic compound has induced a higher growth of seedlings of these crops.
The negative effect of the sodium chloride on dry mass of shoots and roots in response to the increasing $\mathrm{NaCl}$ concentrations, independently of SA use, may be clearly observed on Figures $1 \mathrm{E}$ and $1 \mathrm{~F}$. At the highest $\mathrm{NaCl}$ concentration $(180 \mathrm{mM})$, the low osmotic potential of the medium may be caused decrease on the water potential, leading to less absorption of water and nutrients by root cells; and hence lower seedling development. Moreover, excess $\mathrm{NaCl}$ may have caused the lower flow of nutritional reserves to the embryonic axis.

The electrical conductivity values obtained for the seeds have increased with the increase on $\mathrm{NaCl}$ concentrations (Figures 2A, 2B and 2C), thereby confirming what was detected by the amount of electrolytes released to the soaking solution, i.e., when salt level in the substrate is increased 
the damages caused to cell membranes are also increased proportionally. In overall, when exposed to the different $\mathrm{NaCl}$ concentrations, the seeds treated with $1 \mathrm{mM}$ AS had lower electrical conductivity values for non-treated seeds with such substance, except in the $24 \mathrm{~h}$ imbibition period, where the lowest values for electrical conductivity were observed; thereby attesting the lowest destabilization of cell membranes; and therefore characterizing the defense function of such compound to the high levels of salt stress to which these seedlings were subjected (Figure 2C). Confirming these results, it may be cited the study carried out by Silveira et al. (2000) who, in evaluating electrical conductivity of rice seeds subjected to different salicylic acid concentrations (zero, 0.1 , and $1.0 \mathrm{mM}$ ) also observed similar responses for the same parameters, however without showing any influence these SA concentrations on the seedling growth.
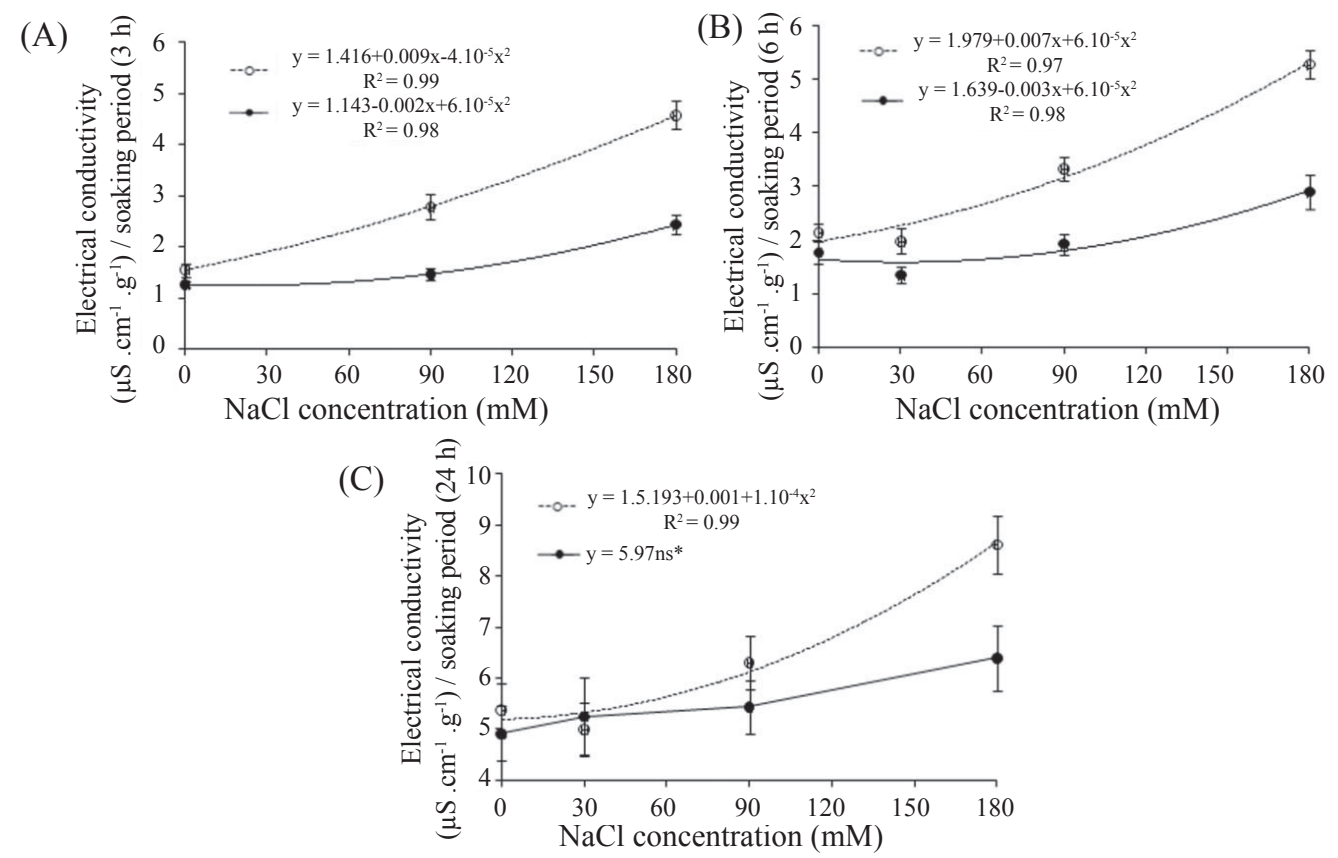

Figure 2. Linear regression curves plotted to mean values of four replications computed for three different imbibition periods of maize seeds, in function of different $\mathrm{NaCl}$ concentrations in the imbibition solution $(\rightarrow-)$, or in function of imbibition periods in distilled water without salicylic acid $(--\circ)$. ns* $=$ non-significant by $\mathrm{F}$ test $(\mathrm{P}<0.05)$. Bars $=$ standard error of the means of four replications.

Although salicylic acid have been able to minimize the effects of different concentrations of the $\mathrm{NaCl}$ solutions on germination of corn seeds (Figure 1A), generally the same effect was not observed in the maintenance of seed vigor (Figures 1B, 1C, 1D, 1E and 1F). Likewise, in a study conducted to evaluate the effect of salicylic acid in pot marigold seeds subjected to different stress types, both thermal as water stress, Carvalho et al. (2007) have also found that this acid had a positive influence on percent germination of seeds.

Among enzymes involved on removal of ROS, which are formed under severe stress situations, the SOD is the first defense line against oxidative stress (Pompeu et al., 2008; Pereira et al., 2012). The activity of this enzyme has shown differences statistically significant values $(p<0.02265)$ with increasing concentrations of $\mathrm{NaCl}$ in the soaking solution, thus evidencing the drastic drop in its activity at the highest concentration of $\mathrm{NaCl}$ used ( $180 \mathrm{mM} \mathrm{NaCl})$, both in seedlings originating from seeds treated with AS, as in seedlings originating from seeds non-treated with such acid. These results indicate that, under the stress conditions to which they were submitted, the stress was severe to the point the antioxidant defense system was not able to be started, or then was saturated (Figure 3A). A possible explanation for this response is that excess $\mathrm{NaCl}$ in the soil may have impaired absorption of some chemical nutrients, including some considered essential for the activity of antioxidant enzymes, such as the elements copper, zinc, manganese, and sulfur that, when lacking, may impair the functionality of SOD enzyme.

The radical superoxide produced under stress condition is toxic and generally is rapidly dismutated by SOD to $\mathrm{H}_{2} \mathrm{O}_{2}$, which is a relatively stable compound that can be detoxified by the catalase and peroxidases (KatGs). These metaloenzymes 
constitute an important primary defense of cells against superoxide radicals generated under stress conditions (Jaleel et al., 2007), hence by the increased SOD activity, mainly between
0 and $30 \mathrm{mM} \mathrm{NaCl}$, it was verified that the maize seedlings presented tolerance to the salt stress until $90 \mathrm{mM} \mathrm{NaCl}$, and above such concentration their drop was prominent (Figure 3A).
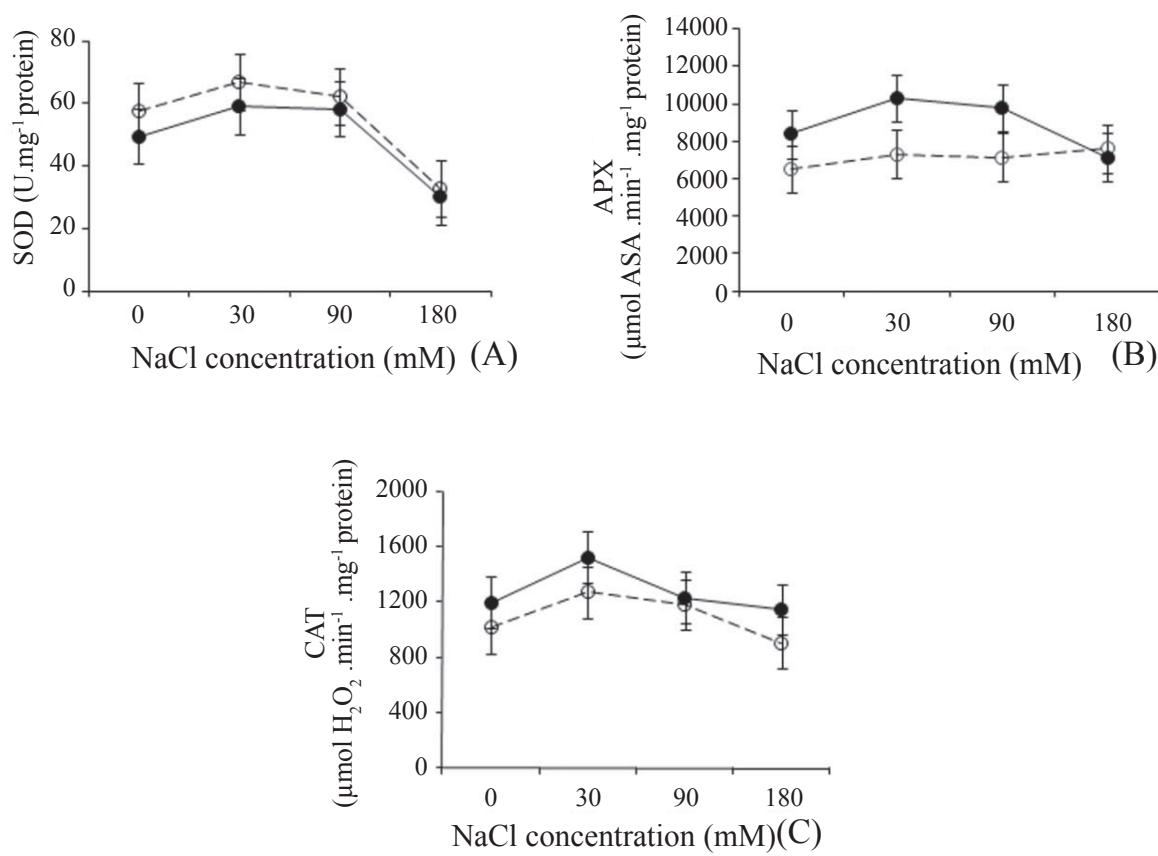

Figure 3. Linear regression curves plotted to data achieved for activity of enzymes SOD (A), APX (B), and CAT (C) in maize seedlings originating from seeds treated with $1 \mathrm{mM}$ salicylic acid (SA) ( - - ), and non-treated with AS (--॰-- ), and subjected to different $\mathrm{NaCl}$ concentrations. Bars = standard error of the mean of four replications.

Activity of enzymes APX and CAT do not shown differences statistically significant between values achieved $(\mathrm{p}<0.664458$ and $\mathrm{p}<0.278099$, respectively) neither in relation to $\mathrm{NaCl}$ concentrations (Figures $3 \mathrm{~B}$ and $3 \mathrm{C}$ ) nor in relation to the treatments with and without application of $1 \mathrm{mM}$ salicylic acid; however it was possible verifying that the highest values to activity of enzyme APX were found in the seeds treated with SA subjected to the intermediate concentrations of 30 and $90 \mathrm{mM} \mathrm{NaCl}$ (Figure 3B). Such results show that antioxidant defense system, as well as salicylic acid application was efficient on removal of ROS originating from the response of seeds to the concentration of $90 \mathrm{mM} \mathrm{NaCl}$; but with more intense activity at the concentration of $30 \mathrm{mM} \mathrm{NaCl}$; what corroborates results verified for the SOD enzyme.

The increase of APX enzyme may explain the maintenance of the $\mathrm{H}_{2} \mathrm{O}_{2}$ levels as indicators of the stress, since this enzyme has a low Michaelis-Menten constant $(\mathrm{Km})$ for this substrate, characterizing higher affinity to $\mathrm{H}_{2} \mathrm{O}_{2}$ than the CAT enzyme (Deuner et al., 2011; Carvalho et al., 2011). The $\mathrm{H}_{2} \mathrm{O}_{2}$, for being easily diffused across cell membranes, acts as signaling molecule in the activation of expression of genes related to the stress responses (Scandalios, 2002). When $\mathrm{H}_{2} \mathrm{O}_{2}$ levels surpass the capacity of APX enzyme detoxification they stimulate the CAT enzyme activity, what has probably occurred in this study when the seeds were subjected to concentration of $30 \mathrm{mM} \mathrm{NaCl}$, since at this concentration there has been an increase on CAT activity, what was reflected in the high levels of $\mathrm{H}_{2} \mathrm{O}_{2}$, and in the need of seedlings to adapt themselves to adverse conditions (Figure 3C). However, from $30 \mathrm{mM} \mathrm{NaCl}$, there has been a drop in the CAT enzyme activity, which decreased until the highest studied sodium chloride concentration (180 mM), thus suggesting that these higher $\mathrm{NaCl}$ concentrations might have caused the salt stress, impairing even the antioxidant system enzymes, what was also characterized by the growth parameters (GSI, IVE, and length and dry mass of shoots and roots) observed in the maize seedlings (Figure 1). Similar results to those found in this study were also found by Cargnelutti et al. (2006) in studies performed with cucumber (Cucumis sativus L.) seeds exposed to mercury, where the stress caused by high concentrations of this element inhibited antioxidant enzymes system activity; by Prodanovic et al. (2012), on the effect of the stress caused by cadmium on the antioxidative enzymes during germination of Serbian spruce [Picea omorika (Pančić) Purkyně] seeds; by Demirkaya et al. (2010), in a study on changes occurring in the antioxidant enzymes during aging 
of onion (Allium cepa L.) seeds; and by Chauhan et al. (2011) in studies on changes in the activity of storage enzymes of wheat seeds naturally aged, or under accelerated aging.

Reduction on activity of APX and CAT enzymes, as measured by electrical conductivity of the soaking solution and obtained in the highest concentrations of $\mathrm{NaCl}(90$ and $180 \mathrm{mM}$ ) may have favored the accumulation of $\mathrm{H}_{2} \mathrm{O}_{2}$ and caused damage to cell membranes of the seedlings subjected to the salt stress. Through responses observed by the leakage of electrolytes to the soaking solution, the seeds subjected to the highest concentrations of sodium chloride without SA application were those that possibly had a greater destabilization of cell membranes system, and hence a lower activity of the antioxidant defense system; which may have been the factor responsible for the low vigor of the seeds (Figure 2) and by the reduced ability of seedling to bypass the stress induced by these high $\mathrm{NaCl}$ concentrations (Figure 3 ).

However, differently from results obtained within this study, Farooq et al. (2009) have reported that exogenous application of salicylic acid on seeds and leaves of rice, at concentrations of 50, 100, and $150 \mathrm{mg} . \mathrm{L}^{-1}$ has stimulated the antioxidant enzymes activity within the seedlings subjected to the water stress imposed. Nevertheless, it should be stressed that, in that study, the rice seeds were incubated in the different SA concentrations during a $48 \mathrm{~h}$ period.

Maintenance of the high activity levels of the antioxidant enzymes SOD, APX, and CAT under water stress or salt stress is essential to keep the balance between formation and removal of ROS in the intracellular environment, and for the peroxidation of lipids of cell membranes is reduced (Eyidogan and Oz, 2007; Deuner et al., 2011). However, characteristics observed in this study, especially at the concentration of 30 $\mathrm{mM}$ sodium chloride, when the antioxidant defense system was less intensely triggered, may explain the increased vigor of the seedlings originating from the seeds germinated under this $\mathrm{NaCl}$ concentration, in relation to higher concentrations of $\mathrm{NaCl}$ (90 and $180 \mathrm{mM}$ ) (Figure 3). Under these two $\mathrm{NaCl}$ concentrations, the antioxidant enzymes have presented low activity; thus demonstrating that under those conditions the damages caused by salt stress cannot be reversed.

\section{Conclusions}

The salicylic acid application minimizes the damages induced by the salt stress on maize seed germination by favoring their germination percent at high $\mathrm{NaCl}$ concentrations in the substrate of until $90 \mathrm{mM}$; however above such concentration $\mathrm{SA}$ is not able to maintain the seed vigor.

The activity of the antioxidant enzymes SOD, APX and
CAT is increased until a $30 \mathrm{mM} \mathrm{NaCl}$ concentration in the substrate; however above such concentration the activity of these enzymes is reduced.

\section{Acknowledgments}

The authors would like to thank the Coordination of Improvement of Higher Education Personnel (CAPES) for the financial support provided to carry out this study; and to the Pioneer Corporation for providing the hybrid corn seeds used in the experiments.

\section{References}

AMORIM, A.V.; GOMES-FILHO, E.; BEZERRA, M.A.; PRISCO, J.T.; LACERDA, C.F. Respostas fisiológicas de plantas adultas de cajueiro anão precoce à salinidade. Revista Ciência Agronômica, v.41, p.113-121, 2010. $<$ http://ccarevista.ufc.br/seer/index.php/ccarevista/article/view/371/415>

APEL, K.; HIRT, H. Reactive oxygen species: metabolism, oxidative stress, and signal transduction. Annual Review of Plant Biology, v.55, p.373-399, 2004. <http://www.heribert-hirt.info/pdf/prr85_ros.pdf>

AZEVEDO, R.A.; ALAS, R.M.; SMITH, R.J.; LEA, P.J. Response of antioxidant enzymes to transfer from elevated carbon dioxide to air and ozone fumigation, in the leaves and roots of wild-type and a catalase-deficient mutant of barley. Physiology Plantarum, v.104, n.2, p.280-292, 1998. <http:// onlinelibrary.wiley.com/doi/10.1034/j.1399-3054.1998.1040217.x/abstract>

BUENO, L.C.S.; MENDES, A.N.G.; CARVALHO, S.P. Melhoramento de plantas: princípios e procedimentos. Lavras-MG: UFLA, 2006. 319 p.

BRADFORD, M.M. A rapid and sensitive method for the quantification of microgram quantities of protein utilizing the principle of protein-dye binding. Analytical Biochemistry, v.72, n.2, p.248-254, 1976. <http:/www.ciens.ucv. ve:8080/generador/sites/lab-bioqgen/archivos/Bradford\%201976.pdf>

BRASIL. Ministério da Agricultura, Pecuária e Abastecimento. Regras para análise de sementes. Ministério da Agricultura, Pecuária e Abastecimento. Secretaria de Defesa Agropecuária. Brasília: MAPA/ACS, 2009. 395p.http:/ www.bs.cca.ufsc.br/publicacoes/regras $\% 20$ analise $\% 20$ sementes.pdf

CARGNELUTTI, D.; TABALDI, L.A.; SPANEVELLO, R.M.; JUCOSKI, G.O.; BATTISTI, V.; REDIN, M.; LINARES, C.E.B.; DRESSLER, V.L.; FLORES, E.M.M.; NICOLOSO, F.T.; MORSCH, V.M.; SCHETINGER, M.R.C. Mercury toxicity induces stress in growing cucumber seedlings. Chemosphere, v.65, n.6, p.999-1006, 2006. <http://www.sciencedirect.com/ science/article/pii/S0045653506003456>

CARVALHO, P.R.; MACHADO NETO, N.B.; CUSTÓDIO, C.C. Ácido salicílico em sementes de calêndula (Calendula officinalis L.) sob diferentes estresses. Revista Brasileira de Sementes, v.29, n.1, p.114-124, 2007. <http:// www.scielo.br/pdf/rbs/v29n1/16.pdf>

CARVALHO, F.E.L.; LOBO, A.K.M.; BONIFACIO, A.; MARTINS, M.O.; LIMA NETO, M.C.; SILVEIRA, J.A.G. Aclimatação ao estresse salino em plantas de arroz induzida pelo pré-tratamento com $\mathrm{H}_{2} \mathrm{O}_{2}$. Revista Brasileira de Engenharia Agricola e Ambiental, v.15, n.4, p.416-423, 2011. <http:// www.scielo.br/pdf/rbeaa/v15n4/v15n04a14.pdf> 
CHAUHAN, D.S.; DESWAL, D.P.; DAHIYA, O.S.; PUNIA, R.C. Change in storage enzymes activities in natural and accelerated aged seed of wheat (Triticum aestivum). Indian Journal of Agricultural Sciences, v.81, n.11, p.1037-1040, 2011. <http://agristudy.com/sites/default/files/Change $\% 20$ in $\% 20$ storage $\% 20$ enzymes $\% 20$ activities $\% 20$ in $\% 20$ natural $\% 20$ and $\% 20$ accelerated $\% 20$ aged $\% 20$ seed $\% 20$ of $\% 20$ wheat $\% 20$ (Triticum\%20aestivum).pdf >

DEEF, E.H. Influence of salicylic acid on stress tolerance during seed germination of Triticum aestivum and Hordeum vulgare. Advances in Biological Research, v.1, n.1-2, p.40-48, 2007. <http://idosi.org/abr/1 (1-2)/7.pdf>

DEUNER, C.; MAIA, M.S.; DEUNER, S.; ALMEIDA, A.; MENEGHELLO, G.E. Viabilidade e atividade antioxidante de sementes de genótipos de feijãomiúdo submetidos ao estresse salino. Revista Brasileira de Sementes, v.33, n.4, p.711-720, 2011. <http://www.scielo.br/pdf/rbs/v33n4/13.pdf>

DEMIRKAYA, M.; DIETZ, K.J.; SIVRITEPE, H.O. Changes in antioxidant enzymes during aging of onion seeds. Notulae Botanicae Horti Agrobotanici, v.38, n.1, p.49-52, 2010. <http://notulaebotanicae.ro/nbha/article/ viewPDFInterstitial/4575/4417>

EYIDOGAN, F.; OZ, M.T. Effect of salinity on antioxidant responses of chickpea seedlings. Acta Physiology Plant, v.29, n.5, p.48-493, 2007. <http:// link.springer.com/article/10.1007\%2Fs11738-007-0059-9?LI=true>

EL-SHABRAWI, H.; KUMAR, B.; KAUL, T.; REDDY, M.K.; SILNGLAPAREEK, S.L.; SOPORY, S.K. Redox homeostasis, antioxidant defense, and methylglyoxal detoxification as markers for salt tolerance in Pokkali rice. Protoplasma, v.245, n.1-4, p.85-96, 2010. <http://link.springer.com/ article $/ 10.1007 \% 2$ Fs00709-010-0144-6? LI=true $>$

FAO - Food and Agriculture Organization of the United Nations. Statistical databases production crops primary. 2006. Disponível em: < http://faostat. fao.org/site/567/default.aspx $>$ Accessed on: Feb. $22^{\text {th }} 2013$.

FAROOQ, M.; BASRA, S.M.A.; WAHID, A.; AHMAD, N.; SALEEM, B.A. Improving the drought tolerance in rice by exogenous application of salicylic acid. Journal Agronomy \& Crop Science, v.95, n.4, p.237-246, 2009. < http:// onlinelibrary.wiley.com/doi/10.1111/j.1439-037X.2009.00365.x/abstract;jse ssionid=5373843D47FCDFFEE8188A4E62BC9DBE.d02t02?deniedAccess CustomisedMessage $=\&$ userIsAuthenticated $=$ false $>$

FORMAN, H.J.; MAIORINO, M.; URSINI, F. Signaling functions of reactive oxygen species. Biochemistry, v.49, n.5, p.835-842, 2010. <http:// pubs.acs.org/doi/abs/10.1021/bi9020378>

GIANNOPOLITIS, C.N.; RIES, S.K. Superoxide dismutases. Occurrence in higher plants. Plant Physiology, v.59, p.309-314, 1977. <http://www. plantphysiol.org/content/59/2/309.full.pdf>

GUNES, A.; INALA, A.; ALPASLANA, M.; ERASLANA, F.; BAGCIA, E.G.; CICEKA, N. Salicylic acid induced changes on some physiological parameters symptomatic for oxidative stress and mineral nutrition in maize (Zea mays L.) grown under salinity. Journal of Plant Physiology, v.164, n.6, p.728-736, 2007. <http://www.sciencedirect.com/science/article/pii/ S0176161706000496>

ISLÃ, R.; ARAGUÉS, R. Yield and plant ion concentrations in maize (Zea mays L.) subject to diurnal and nocturnal saline sprinkler irrigations. Field Crops Research, v.116, n.1-2, p.175-183, 2010. <http://www.sciencedirect. com/science/article/pii/S0378429009003542>
JALEEL, C.A.; MANIVANNAN, P.; SANKAR, B.; KISHOREKUMAR, A.; GOPI, R.; SOMASUNDARUM, R.; PANNEERSELVAN, R. Water deficit stress mitigation by calcium chloride in Catharanthus roseus: effects on oxidative stress, praline metabolism and indole alkaloid accumulation Colloids and Surfaces B: Biointerfaces, v. 60, n.1, p.110-116, 2007. <http:// www.sciencedirect.com/science/article/pii/S0927776507002470>

JALEEL, C.A.; GOPI, R.; GOMATHINAYAGAM, M.; PANNEERSELVAM, R. Effects of calcium chloride on metabolism of salt-stressed Dioscored rotundata. Acta Biologica Cracoviensia Series Botanica, v.50, n.1, p.63-67, 2008. <http://www.ib.uj.edu.pl/abc/pdf/50_1/Jaleel_etal.pdf $>$

JOSEPH, B.; JINI, D. Development of salt tress-tolerant plants by gene manipulation of antioxidant enzymes. Asian Journal of Agricultural Research, v.5, n.1, p.17-27, 2011. <http://scialert.net/qredirect. php?doi=ajar.2011.17.27\&linkid=pdf $>$

KHAN, M.H.; PANDA, S.K. Alterations in root lipid peroxidation and antioxidative responses in two rice cultivars under $\mathrm{NaCl}$-salinity stress. Acto Physiologiae Plantarum, v.30, n.1, p.81-89, 2008. <http:/link.springer.com/ article/10.1007\%2Fs11738-007-0093-7?LI=true>

LYNN, D.G.; CHANG, M. Phenolic signals in cohabitation: implications for plant development. Annual Review of Plant Physiology and Plant Molecular Biology, v.41, p.497-526, 1990. <http://www.annualreviews.org/doi/ abs/10.1146/annurev.pp.41.060190.002433?journalCode $=$ arplant.2>

MACHADO, A.A.; CONCEIÇÃO, A.R. WinStat - Sistema de Análise Estatística para Windows versão 2.0. Universidade Federal de Pelotas, 2007.

MAGUIRE, J.D. Speed of germination aid in selection and evaluation for seedling emergence and vigor. Crop Science, v.2, n.2, p.176-177, 1962. $<$ https://www.crops.org/publications/cs/abstracts/2/2/CS0020020176>

MARINI, P.; BANDEIRA, J.M.; BORBA, I.C.G.; MARTINS, A.B.N.; MORAES, D.M.; AMARANTE, L.; VILLELA, F.A. Antioxidant activity of corn seeds after thermal stress. Ciência Rural, v.43, n.6, p.951-956, 2013. http://www.scielo.br/pdf/cr/v43n6/a16513cr2012-0053.pdf

MØLLER, I. M.; JENSEN, P. E.; HANSSON, A. Oxidative modifications to cellular components in plants. Annual Review of Plant Biology, v.58, p.459-481, 2007. http://www.annualreviews.org/doi/abs/10.1146/annurev. arplant.58.032806.103946

NAKANO, Y.; ASADA, K. Hydrogen peroxide is scavenged by ascorbate specific peroxidase in spinach chloroplasts. Plant and Cell Physiology, v.22, n.5, p.867-880, 1981. <http://pcp.oxfordjournals.org/content/22/5/867>

PACHECO, A.C.; CUSTÓDIO, C.C.; MACHADO NETO, N.B.; CARVALHO, P.R.; PEREIRA, D.N.; PACHECO, J.G.E. Germinação de sementes de camomila [Chamomilla recutita (L.) Rauschert] e calêndula (Calendula officinalis L.) tratadas com ácido salicílico. Revista Brasileira Plantas Medicinais, v.9, n.1, p.61-67, 2007. <http://www.sbpmed.org.br/ download/issn 07 1/artigo9 v9 n1.pdf $>$

PARIDA, A.K; DAS, A.B. Salt tolerance and salinity effects on plants: a review. Ecotoxicology and Environmental Safety, v. 60, n. 3, p. 324-349, 2005. <http://www.sciencedirect.com/science/article/pii/S0147651304000922>

PEREIRA, J.W.L.; FILHO, P.A.M., ALBUQUERQUE, M.B., NOGUEIRA, R.J.M.C.; SANTOS, R.C. Mudanças bioquímicas em genótipos de amendoim submetidos a déficit hídrico moderado. Revista Ciência Agronômica, v.43, n.4, p.766-773, 2012. $<\mathrm{http} / /$ www.scielo.br/scielo.php?script=sci_ pdf\&pid $=S 180666902012000400019 \& \operatorname{lng}=$ en\&nrm=iso\&tlng $=$ pt $>$ 
POMPEU, G.B.; GRATÃO, P.L.; VITORELlO, V.A.; AZEVEDO, R.A. Antioxidant isoenzyme responses to nickel-induced stress in tobacco cell suspension culture. Scientia Agricola, v.65, n.5, p.548-552, 2008. <http:// www.scielo.br/pdf/sa/v65n5/a15v65n5.pdf>

PRODANOVIC, O.; PRODANOVIĆ, R.; PRISTOV, J.B.; MITROVIĆ, A.; RADOTIĆ, K. Effect of cadmium stress on antioxidative enzymes during the germination of Serbian spruce [Picea omorika (Panc.) Purkyne]. African Journal of Biotechnology, v.11, n.52, p.11377-11385, 2012. <http://www. academicjournals.org/ajb/PDF/pdf2012/28Jun/Prodanovic\%20et\%20al.pdf>

SANTOS, P.R.; RUIZ, H.A.; NEVES, J.C.L.; ALMEIDA, E.F.; FREIRE, M.B.G.S.; FREIRE, F.J. Germinação, vigor e crescimento de cultivares de feijoeiro em soluções salinas. Revista Brasileira de Engenharia Agrícola e Ambiental, v.13, p.882-889, 2009. <http://www.scielo.br/pdf/rbeaa/v13s0/v13s0a10.pdf >

SCANDALIOS, J.G. The rise of ROS. Trends in Biochemical Science, v.27, n.9, p.483-486, 2002. <http://europepmc.org/abstract/MED/12217524/ reload $=0 ;$ jessionid $=$ uydJPpMIOt0cil pmLUPW.0>

SILVEIRA, M.A.M.; MORAES, D.M.; LOPES, N.F. Germinação e vigor de sementes de arroz (Oryza sativa L.) tratadas com ácido salicílico. Revista Brasileira de Sementes, v.22, n.2, p.145-152, 2000. <http://www.abrates.org. br/revista/artigos/2000/v22n2/artigo20.pdf>
SOARES, A.M.S.; MACHADO, O.L.T. Defesa de plantas: Sinalização química e espécies reativas de oxigênio. Revista Trópica-Ciências Agrárias e Biológicas, v.1, n.1, p.9-19, 2007. <http://www.ccaa.ufma.br/revistatropica/Artigos_nr1/ biologia/DefesaDePlantasSinalizacaoQuimicaEEspeciesReativasDeOxigenio_ bio_Ar.pdf>

SOUSA, C.M.M.; SILVA, H.R.; VIEIRA JÚNIOR, G.M.; AYRES, M.C.C.; COSTA, C.L.S.; ARAÚJO, D.S.; CAVALCANTE, L.C.D.; BARROS E.D.S.; ARAÚJO, P.B.M.; BRANDÃO, M.S.; CHAVES, M.H. Fenóis totais e atividade antioxidante de cinco plantas medicinais. Química Nova, v.30, n.2, p.351-355, 2007. <http://www.scielo.br/pdf/qn/v30n2/20.pdf>

STEEL, R.G.D.; TORRIE, J.H. Principles and procedures of statistics: a biometrical approach. New York, NY: McGraw-Hill Book Co, 1980. 633p.

SZEPESI, A.; CSISZÁR, J.; BAJKÁN, S.; GÉMES, K.; HORVÁTH, F.; ERDEI, L.; DEÉR, A.K.; SIMON, M.L.; TARI, I. Role of salicylic acid pretreatment on the acclimation of tomato plants to salt- and osmotic stress. Acto Biologica Szegediensis, v.49, n.1-2, p.123-125, 2005. <http://ttkde4.sci.uszeged.hu/ABS/2005/Acta\%20HP/49123.pdf>

VIEIRA, R.D.; KRZYZANOWSKI, F.C. Teste de condutividade elétrica In: KRZYZANOWSKI, F.C.; VIEIRA, R.D.; FRANÇA-NETO, J.B. (Ed.) Vigor de sementes: conceitos e testes. Londrina: ABRATES, 1999. p.4.1-4.26. 